\title{
Linkage Between Economic Growth and Income Inequality in Ethiopia
}

\author{
Gashaw Getaye \\ Economics Department, Debark University, Debark, Ethiopia
}

Email address:

gizagetaw121@gmail.com

\section{To cite this article:}

Gashaw Getaye. Linkage Between Economic Growth and Income Inequality in Ethiopia. International Journal of Sustainability Management and Information Technologies. Vol. 7, No. 1, 2021, pp. 1-10. doi: 10.11648/j.jjsmit.20210701.11

Received: December 10, 2020; Accepted: December 23, 2020; Published: March 12, 2021

\begin{abstract}
There are many macroeconomic and non macro economics factors or variables related to the country's economic growth. Among the most important factors believed to be related to the rate of economic growth, the issue of income inequality in the process of national income distribution is the vital one. So, understanding the relationship between these two economic variables is important. If there is a clearer understanding about the relationship between income inequality and the rate of economic growth, particular economic policies could be employed in the appropriate manner to deal with income inequality and encourage economic growth. So, main objective of the study is to analyze the linkage between economic growth and income inequality in Ethiopia. The linear regression model is applied in order to investigate the long-run and short run relationship between the dependent variable (real GDP) and included explanatory variable. The result shows that there is a stable long run relationship between real GDP and included variables. And the empirical results reveal that income inequality measured by gini coefficient is found to have negative impact on economic growth. The study has also an important policy implication which implies that economic growth can be improved significantly when the income inequality among people reduced through different redistributive mechanisms.
\end{abstract}

Keywords: Economic Growth, Income Inequality, Gini Coefficient, Ethiopia

\section{Introduction}

Economic growth is the process by which a nation's wealth increases over time and occurs when the productive capacity of a country increases. Economic development takes place when there is accelerated economic growth accompanied by major changes in social structures, popular attitudes and national institutions, reduction of inequality and eradication of poverty [25].

One of the most important factors believed to be related to the rate of economic growth is the issue of income inequality in the process of national income distribution. Understanding the relationship between these two economic variables is important because higher income inequality is often found in lower developed countries. If there is a clearer understanding about the relationship between income inequality and the rate of economic growth, particular economic policies could be employed in the less developed countries in the appropriate manner to deal with income inequality and encourage economic growth [13].
Inequality in income is an economic problem first and it becomes also a political and social problem in modern society. Disparities in income and wealth have tended to dominate the discussion on inequality, not only because they contributes directly to the well-being of individuals and families, but also because they shape the opportunities people have in life as well as their children's future; access to goods and considerable degree of good educational outcomes and good health. Therefore emphasizing on addressing income inequality is not only amoral issue but it is also necessary to inspire human and productive potentials of each country's population to bring development towards socially sustained path [28]. So, because of bi-directional causality linkage, estimating the relationship between economic growth and income inequality will become the fundamental concern of developmental economists.

The focus on the economic growth and income inequality relationship began in the 1950's when Simon Kuznets presented his idea of an inverted $U$ relationship between per capita GNP and inequality in the distribution of income. 
Kuznets had proved the hypothesis of a curve inverted Ushaped by linking the Gross Domestic Product per capita (GDP per capita) to the level of inequality in income distribution. This hypothesis predicts that, the unequal distribution of income seems endogenous to development process. In fact, in the first time, the development process tends to increase inequality, but beyond a certain threshold, the trend is reversed, inequality stabilizes, then decrease until it reaches the lowest level as a country achieve its higher level of per capita income. The inverted U-shaped hypothesis of Kuznets shows that the process of economic development reflects a transition from an agrarian economy with low productivity to an industrial economy with high productivity. So, Kuznets state that, inequality increases at the early stages of development due to the process of industrialization which leads to a shift of labor force from agricultural sector to industrial sector and latter inequality tends to decline as labor force in industrial sector diversified and that of agricultural sector declines [15].

Even though the earliest attempt to correlate income inequality with economic growth was investigated by Simon Kuznets [15], there are several studies that suggests growth does not have an impact on inequality [10] and more recently [9], and others have found that there is positive linkage between income inequality and economic growth [7, 21, 24]. Still other researchers have found either negative or no relationship at all [14, 6, 22, 19].

When we came to Ethiopia, its economy has experienced impressive growth performance over last decades with average Gross Domestic Product (GDP) growth rate of $11 \%$, which is about the double of the average growth for Sub Saharan Africa [28]. According to World Bank report on world development indicators (WDI) [29], the top 10 percent of the population receives 28 percent out of country's total income and in contrast to the bottom 20 percent of the population receives only 8 percent of a country's total income. So, even though this paper does not provide the definitive answer on the relationship between economic growth and income inequality, it attempt to contribute additional relevant evidence to show the linkage between economic growth and income inequality in Ethiopia.

\section{Statement of the Problem}

The analysis of growth-inequality linkage has a long tradition in economics literature. These papers have largely focused on whether countries will have to face trade-off between reducing income inequality and improving economic growth performance, or instead whether there exists a vicious circle in which economic growth leads to lower income inequality with low income inequality in turn leading to faster economic growth. These are the main points of argument around which the debate revolves [28].

Kuznets first investigated economic growth and income inequality relationship in 1955 . He tried to answer the questions; Does inequality in the distribution of income increase or decrease in the course of a country's economic growth? What factors determine the secular level and trends of income inequalities? According to Kuznets, the level of economic development is related to the degree of income inequality. Income inequality tends to increase during the early stages of economic growth, then levels off, and finally decreases during later stages. The Kuznets curve illustrates this relationship; the level of inequality first rises at the early phases of economic growth and then starts declining at the later phases of economic growth. The Kuznets curve is an inverted U-shaped curve. Kuznets describes a positive relationship between income inequality and economic growth at the early phases of growth and a negative relationship in the later phases [15].

Many studies have been also conducted to examine the linkage between economic growth and income inequality in different countries for different period of time. In Ethiopia, unlike the papers that focuses on the interaction between growth, inequality and poverty, which to a large extent have been written over the last two decades, the analyses of growth-inequality linkage has given attention by few researchers.

Beza Girma [5] tried to investigate the relationship between income inequality and economic growth in Ethiopia for the period 1995-2008. This paper used descriptive method of analysis and it concluded that there is a positive linkage between economic growth and income inequality i.e. as growth is attained inequality between society increases. However, this study does not show other variables like, urbanization and labor force growth, that can affect the system and it does not show how economic growth significantly and positively related to income inequality.

Abdurrahman Bedewialso tried to investigate the possible impact of inequality on economic growth focusing on 12 African countries including Ethiopia for the period between 1970 and 2000. The result of the study shows that there exist a link between income inequality and economic growth in all countries with different degree of association. However, this paper also focused only on the direct impact of income inequality on economic growth without considering other explanatory variables like, urbanization and financial development, which affect the system. This study has also a problem that there is no appropriate test of stationary and cointegration that have to be taken to avoid statistical problems.

Gideon Bulla [12] also tried to examine the relationship between economic growth and income inequality in Ethiopia for the period of 1996-2011. The result of the studies indicated that economic growth has a negative influence on income inequality. However, the work of Gideon has the problem of omission of relevant variable like government expenditure and inflation were not included as explanatory variables in the model. And also it used data of short time period, which makes the reliability of the results so week.

More recently, Abdurohman Hassen tried to assess economic growth-income inequality nexus in Ethiopian economy. This study was conducted based on both the econometric and descriptive analysis by taking income inequality as an independent variable and economic growth 
as a determinant variable. The final conclusion of the study shows that, economic growth measured by real GDP per capita has negative and significant effect on income inequality. But, this study was conducted by using short time span of data (only 15 years) i.e. for the period only 19962011, which makes the final conclusion questionable.

Generally, there are many studies on the issue of relationship between economic growth and income inequality at international level, and there are also studies that were made to examine the linkage between economic growth and income inequality in case of Ethiopia. However, as shown above, these studies have their own knowledge gaps. So, this paper tries to fill these gaps by using available data and tries to further investigate the relationship between economic growth and income inequality by taking economic growth as a function of income inequality and by further expanding the time period for 35 years from 1980-2014 in addition to including the above listed variables.

\section{Objectives of the Study}

The objectives of this study is to investigate the effect of income inequality on economic growth and test whether the relation between them follow Kuznets inverted U-hypothesis in Ethiopian case. And to examine the factors that explains economic growth.

\section{Literature Review}

In economics the link between economic growth and income inequality became the main concern for more than half a century. Many works have been developed to explore the complex relationship between income inequality and economic growth, which come-up with different conclusion or results. This chapter summarizes previous work done on this area.

The pioneer for this work was Simon Kuznets [15], who suggested that the relationship between economic growth and income inequality can be shown by inverted U-shape, in which at the early stage of development income inequality increases, reaches a maximum point at an intermediate level of income and then eventually declines. This hypothesis is known as the inverted U- hypothesis. This paper is also an attempt to examine the linkage between economic growth and income inequality in Ethiopia case. However, before analyzing the link between them let's look at some theoretical and empirical literatures.

\subsection{Economic Growth and Its Measurement}

Economic growth is the increase in per capita domestic product (GDP) or other measures of aggregate income and measured as the rate of change in real gross domestic product (GDP). It can beeither positive or negative. Negative economic growth can be referred by saying the economy is shrinking and it is associated with economic recession and economic depression. And it occurs when the production possibility frontier (PPF) shifts upward and outward to the right, so that combinations of goods and services that were unattainable can now be produced. Specifically GDP per capita is the most common measures of overall level of economic activities [26]. This study used the annual increment in real gross domestic product (GDP) as the measure of economic growth.

\subsection{Income Inequality and Its Measurements}

Inequality is the degree to which distribution of economic welfare generated in an economy differs from that of equal shares among its inhabitants [23]. Inequality is observed not only in incomes but also in terms of social exclusion and the inability to access social services and socio-political rights by different population groups, genders and even races. Inequality in income will be the main focus in this paper. Income inequality means that one segment of the population has a disproportionately large share of income compared to other segments of that population [18].

Measuring income inequality is more complex. As a measure of income inequality, many different indicators can be used. One of the most frequently used indicators of inequality is the Gini coefficient, which is calculated as a ratio-the area between the Lorenz curve and the 45 degrees equality line divided by the entire area below the 45 degrees line. The higher the Gini coefficient, the more unevenly is income divided among the population.

Gini coefficient: A numerical measure of income inequality ranging from 0 (perfect equality) to 1 (perfect inequality). Deaton defines the Gini coefficient as: "the average difference in income between all pairs of people divided by the average income" [13]. The higher the value of the coefficient, the higher the inequality of income distribution; the lower it is, the more equal the distribution of income. This is also known as the Gini concentration ratio.

\subsection{Factors Influencing Economic Growth and Income Inequality}

The economic growth of a country may retard due to a number of factors. Some of the important factors that affect the economic growth of a country. Among these human resource, natural resources, capital formation, technological development, social and political factors are the major factors influence economic growth.

Banerjee A. and Duflo E [4], also classified different factors affecting inequality which includesthe economic growth and the overall development level of a country, macroeconomic factors (inflation, unemployment, the size of government's expenditure, external debt and foreign reserves, changes in the exchange rate), demographic factors (age structure of population, the growth and density of population, urbanization, level of human capital, including the level of education and health condition of population), political factors (privatization and the share of the private sector, level of taxes and the share of the public sector, openness of a country, especially trade openness and freedom of labor movement; social policy and other decisions of economic 
policy), historical, cultural and natural factors (distribution of land ownership, people's attitude to inequality, extent of shadow economy).

\subsection{The Relationship Between Economic Growth and Income Inequality}

Theory shows that income inequality is a condition that prevails along with economic growth. According to the utilitarian view, income inequality must exist along with the economic growth in order to maximize social welfare. This is in sharp contrast to the egalitarian view according to which, all members of the society should have equal access to all economic resources in terms of economic power, wealth and contribution. Kuznets [15] introduced the inverted U-shaped Kuznets curve that showed that in an economic system, at the initial level of low economic growth, income inequality is low and as growth occurs, income inequality increases till a threshold, after which, income inequality decreases with increased economic growth.

In the theoretical literature, there are three main arguments for the detrimental impact of inequality on growth. The first is the political economy argument [2], which is based on the following three premises: (i) redistributive government expenditure and taxation are negatively related to growth because of their negative effect on capital accumulation; (ii) taxes are proportional to income but the benefits of public expenditure accrue equally to all individuals, which in turn implies that an individual's preferred levels of taxation and expenditure are inversely related to his income; and (iii) the tax rate selected by the government is the one preferred by the median voter. Taken together, those premises would imply that growth increases as inequality falls.

A second argument for an inequality-to-growth direction of causality relies on the so-called sociopolitical instability approach [1] which can be summarized as follows: (i) highly unequal societies create incentives for individuals to engage in activities outside normal markets, such as crime, etc; and (ii) sociopolitical instability discourages accumulation because of current disruptions and future uncertainty. This approach would also imply that growth increases as inequality falls.

A third argument for the proposition that increases in inequality lead to lower growth is the presence of credit constraints. Galor and Zeira [11], note that if (i) the process of development is characterized by complementarities between physical and human capital so that growth increases as investment in human capital increases; and (ii) credit constraints prevent poorer individuals from investing in education, then inequality will adversely affect growth prospects by reducing the number of individuals who are able to invest in human capital. Similarly Aghion [3], show that if (i) there are decreasing returns with respect to individual capital investments; and (ii) credit imperfections mean that individual investments are an increased function of initial endowments, then inequality would be detrimental to growth by concentrating investment in fewer richer people (with a lower marginal return to investment). It is worth noting here that even if the three arguments above predict that inequality hampers growth, their predictions on the impact of redistribution on growth are different. For example, the political economy argument is based on the premise that progressive distributional change has a negative impact on growth. On this argument, redistribution would negatively affect growth through two different channels. First, it would provide a disincentive to work effort from those on the receiving side. Second, if would discourage investment from those who transfer the bulk of resources. On the other hand, the sociopolitical and credit constraints arguments would predict that redistribution - by increasing political stability and the associated investment in the first case and by creating investment opportunities with a high marginal return in the second case - would have a positive impact on growth.

\subsection{Empirical Reviews}

A large number of empirical studies have attempted to explore the relationship between income inequality and economic growth. Different researchers have used different types of data to study the relationship. This section will summarize previous work done on this area. Among these empirical findings lets us to see the following.

Lee and Roemer [16] studied the political economy of inequality and growth by combining the political economy approach with an imperfect capital market assumption. They show that a high inequality induces a high redistributive tax rate with a median voter political process; a high tax rate chokes off private investment due to the disincentive effect; and any factors detrimental to private investment are harmful to growth. A study by Dahan and Tsiddon [7], investigated the dynamic interactions among demographic transition, income distribution, and economic growth. It showed that fertility and income distribution follow an inverted U-shaped dynamics in the process of economic development. A study by Barro using a broad panel of countries showed little overall relation between income inequality and rates of growth and investment. Panizza [21] used a cross-state panel for the United States to assess the relationship between inequality and growth. And found a negative relationship between inequality and growth. Voitchovsky [27] suggested that inequality at the top end of the distribution is positively associated with growth, while inequality lower down the distribution is negatively related to subsequent growth.

When we came to our country Ethiopia, there are few studies on the relationship between economic growth and income inequality. BezaGirma [5] assessed the link between economic growth and income inequality in Ethiopian case and suggests that, as growth is attend; inequality between the societies increase, leading to the few to hold the most important part of the resources. The society would be in deep poverty and income will be distributed unevenly. Abdurrahman Bedewi, tried to examine the possible relationship between inequality and economic growth in 12 African countries including Ethiopia. And the result showed that, there exist the link between income inequality and economic growth in almost all the countries, with different 
degree of association. GedionBula [22], tried to examine the relationship between economic growth and income inequality in Ethiopia with the help of Kuznets inverted U-hypothesis for the period of 1996-2011. The result of the analysis indicated that real GDP per capita has a negative influence on inequality, which is measured by Gini coefficient.

\section{Model Specification and Methodology}

\subsection{Data Source}

To achieve the above objectives, the study totally uses secondary data sets from the period of 1980 to 2014. The data for Gini coefficient will be collected from MOFED. The data for real GDP, trade openness, government expenditure, inflation, domestic saving and financial development will be collected from national bank of Ethiopia, MOFED. And the data for labor force growth, education level and urbanization rate will be collected from Central Statistical Agency (CSA). Other important data will be obtained from annual report of
World Bank about World Development Indicators (WDI), literatures, economic journals, and internet.

\subsection{Model Specification}

Many economic theories have identified various factors that influence the growth of a country. These factors include natural resources, investment, human capital, innovation, technology, economic policies, foreign aid, trade openness, institutional framework, foreign direct investment, political factors, socio-cultural factors, geography, demography and many others. Economic growth and income inequality are the main variables. The adopted model takes economic growth as the dependent variable and income inequality, education, government expenditures, trade openness, inflation, urbanization, financial development, labor force and domestic saving as an explanatory variable.

The mathematical relationship between economic growth and income inequality and other included determinants are expressed as follows:

Economicgrowtht $=f$ [Income inequality squaredt, Inflationt, Financial developmentt, domestic savigt Government expendturet, Educationt, Urbanizationt, Tradeopennesst, Laborforcet]

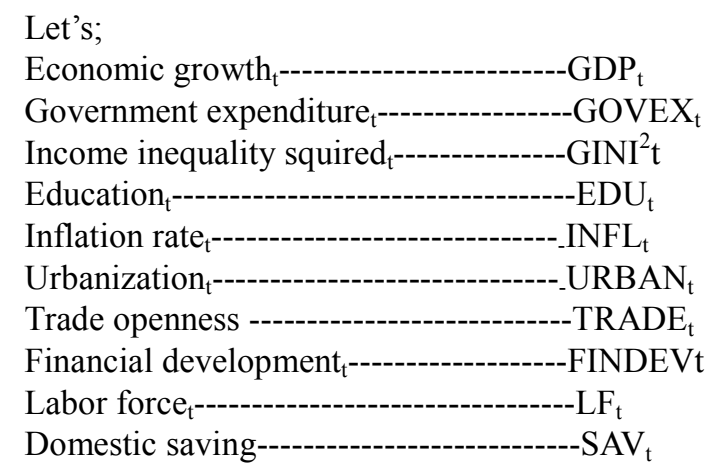

As it was developed in chapter one, the study's main equation have the following from:

$\ln G D P t=\beta o+\beta 1 \ln G I N I^{2} t+\beta 2 I N F L t+\beta 3 F I N D E V t+\beta 4 S A V t+\beta 5 G O V E X t+\beta 6 E D U t+\beta 7 U R B A t+\beta 8 T R A D E t+\beta 9 L F t+E t$

Where; $\beta$ i are constants and $E i$ is the error term.

Table 1. Measurement of the variable.

\begin{tabular}{|c|c|c|c|}
\hline No & Variable & Measurement & Expected \\
\hline 1. & Economic growth & Natural logarithm of Real GDP $(\ln R G D P)$ & sign \\
\hline 2. & Income inequality & Natural logarithm of Gini squared $\left(\ln G I N I^{2}\right)$ & -ve \\
\hline 3. & Inflation rate & Annual percentage change in CPI (consumer price index) & -ve \\
\hline 4. & Financial development & Ratio of broad money to $\operatorname{GDP}\left(\frac{M 2}{G D P}\right)$ & $+\mathrm{ve}$ \\
\hline 5. & Domestic saving & The ratio of Gross Domestic Saving to GDP $\left(\frac{S A V}{G D P}\right)$ & + ve \\
\hline 6. & Government expenditure & Total government expenditure as a percentage of GDP & $+\mathrm{ve}$ \\
\hline 7. & Education & Primary school enrollment rate & + ve \\
\hline 8. & Urbanization & Growth rate of urban population & + ve \\
\hline 9. & Trade openness & Trade to GDP ratio or $\left(\frac{\text { Trade }}{G D P}\right)$ & + ve \\
\hline 10. & Labor force & The ratio of active labor force to total population & + ve \\
\hline
\end{tabular}

\subsection{Description of the Main Variables}

\subsubsection{Economic Growth}

In this study the dependent variable is economic growth which is defined as the long-run expansion of the economy's ability to produce output by increasing the quantity or quality of the economy's resources (labor, capital, land, and entrepreneurship). It is measured by real GDP growth rate. Economic growth related to an increase in real GDP. Real GDP is the total market value, measured in constant prices, 
of all goods and services produced within the political boundaries of an economy during a given period of time, usually one year. The key is that real gross domestic product is measured in constant prices, the prices for a specific base year. Real gross domestic product, also termed constant gross domestic product, adjusts gross domestic product for inflation. So, the increase in real GDP means there is an increase in the value of national output / national expenditure.

\subsubsection{Income Inequality}

One of the major factors that affect economic growth within this specified model is income inequality. Income inequality means that one segment of the population has a disproportionately large share of income compared to other segments of that population. It depends on how income is distributed. Income distribution is a manner in which income is divided among the members of the economy. A certain amount of inequality in the income distribution is to be expected because resources are never equally distributed. Gini index is used as a measure of income inequality, which shows extent to which the distribution of income among individuals or households within an economy deviates from a perfectly equal distribution. Gini index of 0 (zero) represents the distribution is perfectly equal, that is, everyone has exactly the same amount of income or wealth, while an index of 100 implies the distribution is perfectly unequal. There for gini coefficient used as a proxy and the sign of the coefficient would expected to be negative.

\subsection{Econometric Procedure}

\subsubsection{Unit Root Test}

The early and pioneering work on testing for a unit root in time series was done by Dickey and Fuller which we call Augmented Dickey-Fuller (ADF) test. It is also known as tau $(\tau)$ test. So, a time series data is said to be stationary if the computed ADF or $\tau$-value is more negative than critical ADF value or when we take absolute value, a time series data to be a stationary it must fulfill that calculated ADF or $\tau$-value is greater than the critical $\mathrm{ADF}$ value at a given level (calculated $\tau>$ critical $\tau$ ).

\subsubsection{Co-integration Test}

Test for co-integration can be checked by Engle-Granger (EG) or Augmented Engle-Granger (AEG) test on the residual estimating from the co-integrating regression. If the variables are individually non-stationary, there is a possibility that this regression becomes spurious. But when we performed a unit root test on the residual, if the absolute value of calculated Engle-Granger (EG) value is greater than the absolute value of critical (tabulated) Engle-Granger (EG) value ourconclusion is that the estimated residual is stationary (i.e. the co-integrating regression is not spurious even individually they are non-stationary).

\subsubsection{Error Correction Model}

Generally, since ECM is a short run model, the coefficients of the independent variable show the short run relationship of them with the dependent variable. The ECM developed by Engle and Granger is a means of reconciling the short run behavior of an economic variable with its long run behavior.

\subsubsection{Autocorrelation and Multico-linearity}

Durbin Watson d statistic: is the most celebrated test detecting autocorrelation between the errors in different time periods [17]. Detecting multicollinearity by using Variance inflation factors (VIF), which measure how much the variance of the estimated regression coefficients are inflated as compared to when the predictor variables are not linearly related, is important. If $\mathrm{V} \mathrm{IF} \geq 10$, then there is a problem of multicollinearity [20].

\subsection{Descriptive and Econometric Analysis}

\subsubsection{Descriptive Analysis}

i. Trend of real GDP

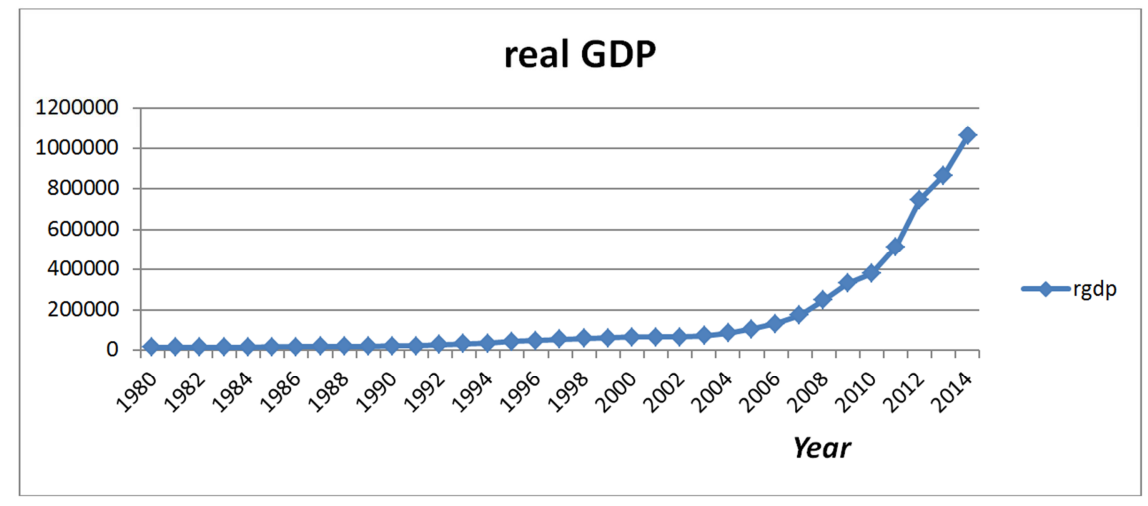

Source; own computation based on NBE.

Figure 1. Real GDP, 1980-2014.

Real GDP which is measured at constant market price is very low in 1980 s due to the given to military expenditure. At the time most of the resources used for military and consolidation of political power rather than the expansion of our put. In the 1990s GDP shows a steady increase, but after 2006/07 it shows very fast increase.

ii. Trend in inequality in income

Trends of income in equality measured by Gini coefficient 
income distribution which is measured by Gini coefficient exhibits or experienced some fluctuation (ups and downs) though 35 years (1980-2014). During the dreg regime even through, there is high income inequality, it shows small fluctuation (not significant) due to the socialist economic system of the period. It starts to increase during the imperial regime; it reaches an absolute minimum of 25 percent \& absolute maximum of 57 percent in 1984 and 2003 respectively.

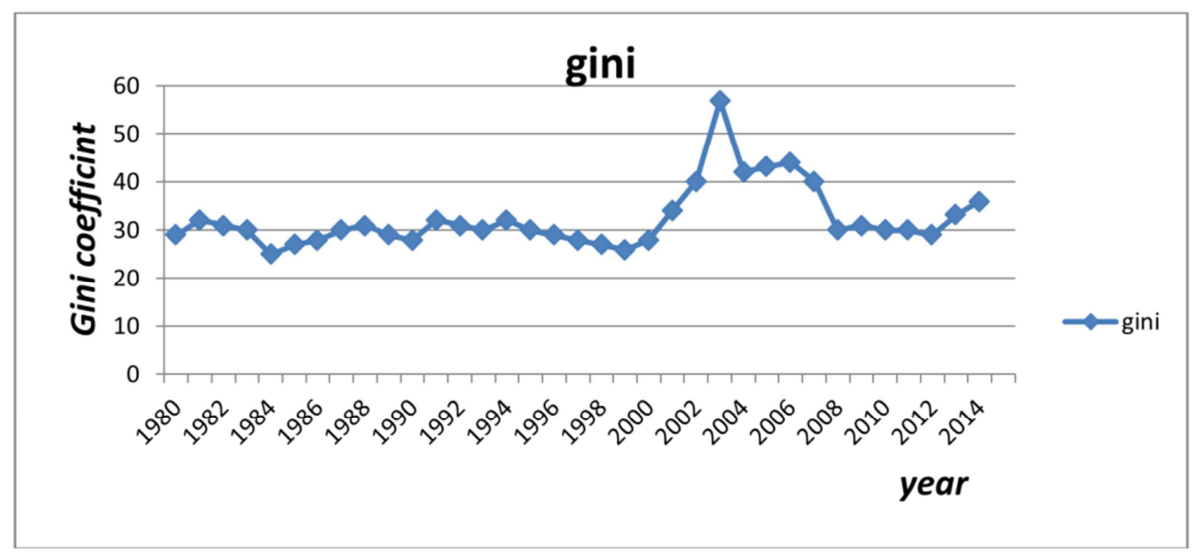

Sources; IMF for (2013 \& 2014) and MoFED

Figure 2. Gini coefficient (\%), 1980-2014.

But during the EPRDF it exhibits an increase trend until 2006, and reaches a relative maximum of 44 percent in 2006 . After this year it shows a contentious decline and reaches a relative minimum of 29 percent in the last estimate of the year 2012. But, it also increases to 33 and 36 percent in the year 2013 and 2014 respectively.

Table 2. Summary of descriptive statistics.

\begin{tabular}{|c|c|c|c|c|c|c|c|c|}
\hline Stats & Min & $\operatorname{Max}$ & mean & sd & Skewnes & Kurtosis & varianc & cv \\
\hline Lny & 9.41 & 13.9 & 11.00 & 1.3203 & 0.710826 & 2.451 & 1.74318 & 0.12 \\
\hline Ingini2 & -2.77 & -1.12 & -2.29 & 0.34707 & 1.511935 & 5.2105 & 0.12046 & -0.1515 \\
\hline Infl & -10.6 & 36.4 & 8.802 & 10.3905 & 0.710839 & 3.7876 & 107.963 & 1.18047 \\
\hline $\mathrm{m} 2$ & 17.2 & 40 & 30.02 & 5.88504 & -0.27064 & 2.462 & 34.6337 & 0.19601 \\
\hline S & 4.72 & 27.9 & 13.30 & 5.62632 & 0.985644 & 3.5485 & 31.6554 & 0.42277 \\
\hline Gov & 15.7 & 29.3 & 21.56 & 3.77216 & 0.340007 & 2.0536 & 14.2292 & 0.17489 \\
\hline Edu & -16.3 & 27.1 & 6.445 & 9.79822 & 0.096879 & 2.9152 & 96.0052 & 1.52025 \\
\hline tradeo & 8.1 & 37.3 & 23.46 & 7.89492 & 0.065082 & 1.9773 & 62.3298 & 0.3365 \\
\hline $\mathrm{Lf}$ & 2.47 & 3.82 & 3.270 & 0.33294 & -0.12962 & 2.8088 & 0.11085 & 0.1018 \\
\hline
\end{tabular}

\subsubsection{Econometric Analysis}

i. Unit root test of stationary

Table 3. Unit root test results.

\begin{tabular}{llll}
\hline \multirow{2}{*}{ Variable } & \multicolumn{2}{l}{ Test statistic } & Stationary at \\
\cline { 2 - 3 } & At level & At first difference & \\
\hline lnGDP & -4.653 & -3.216 & I [0] at $5 \%$ \\
lnGINI & -2.123 & -5.630 & I [1] at $1 \%$ \\
INFL & -3.975 & -7.510 & I [0] at $1 \%$ \\
EINDEV & -2.285 & -4.669 & I [1] at $1 \%$ \\
SAV & -2.277 & -8.202 & I [1] at $1 \%$ \\
GOVEX & -2.208 & -5.312 & I [1] at $1 \%$ \\
EDU & -3.002 & -6.950 & I [0] at $5 \%$ \\
URBAN & -3.134 & -9.182 & I [0] at $1 \%$ \\
TRADEO & -0.986 & -5.913 & I [1] at $1 \%$ \\
LF & -2.318 & -6.584 & I [1] at $1 \%$ \\
Test critical value & -3.689 & Test critical value & \\
$1 \%$ level & -2.975 & $1 \%$ level & -3.696 \\
$5 \%$ level & -2.619 & $5 \%$ level & -2.978 \\
$10 \%$ level & & $10 \%$ level & -2.620 \\
\hline
\end{tabular}

Source: Stata results
The unit root test by Dickey fuller (DF) for the variables is presented in the following table.

The result in Table 3 shows that there is a mixture of I (0) and I (1) but not any order two. As we have seen form table 3, real GDP, inflation rate, primary enrollment rate, and urbanization growth rate are integrated of order zero i.e. I (0) while income inequality (Gini), financial development, gross domestic saving, government expenditure, trade openness and labor force growth are integrated of order one (I (1)). Meaning real GDP, inflation rate, primary enrollment rate, and urbanization growth rate are stationary at level where as income inequality (gini), financial development, gross domestic saving, government expenditure, trade openness and labor force growth are stationary at first difference.

ii. Co integration test

The residual is stationary at $1 \%$ significant level

Since AEG test result is -3.730 , it is stationary at $1 \%$ level I (0), which means the variables are stationary. This shows the existence of long run relationship among the variables. 
Table 4. Co-integration test results.

\begin{tabular}{llllll}
\hline Variable & TestStatistic & $\mathbf{1 \%}$ CriticalValue & $\mathbf{5 \%}$ CriticalValue & $\mathbf{1 0 \%}$ CriticalValue & Stationary at \\
\hline Residual & -3.730 & -3.689 & -2.975 & -2.619 & $\mathrm{I}[0]$ at $1 \%$ \\
\hline
\end{tabular}

\section{iii. Autocorrelation Test}

The Durbin Watson (d) statistic is a number that tests for autocorrelation in the residuals from a statistical regression analysis. The Durbin-Watson statistic is always between 0 and 4. Therefore, as a rule of thumb, if Durban Watson dstatistic is found nearer to the value 2 in an application, one may assume that there is no first order autocorrelation, either positive or negative. Values approaching 0 indicate positive autocorrelation and values approaching toward 4 indicate negative autocorrelation.

\section{Durbin-Watson d-statistic $(10,35)=1.234481$}

\section{iv. Heteroskedasticity Test}

The homoskedasticity assumption states that the variance of unobservable error $\varepsilon_{i \text { conditional on explanatory variable }}$ is constant. Heteroskedasticity occur whenever the variances of unobservable variable changes across different segments of the observations, which are determined by the different value of the explanatory variable. The test has given the following results by using Breusch Pagan test.

Ho: Constant variance
$\operatorname{chi} 2(1)=3.05$
Decision: since p-value is greater than $5 \%$
Prob>
chi2 $=0.0806$ $(0.0806>0.05)$, the null hypothesis is accepted i.e. no problem of hetroskedasticity.

\section{v. Multicolinearity Test}

The Variance Inflation Factor (VIF) is a statistic that can be used to identify multicolinearity in a matrix of predictor variables. "Variance Inflation" refers here to the mentioned effect of multicolinearity on the variance of estimated regression coefficients. The decision rule of multicollinearity as a rule of thumb states that the $\mathrm{VIF}<10$ shows absence of multicollinearity.

Table 5. Multicolinearity test (VIF).

\begin{tabular}{lll}
\hline Variable & VIF & 1/VIF \\
\hline TRADEO & 2.48 & 0.403811 \\
URBA & 2.26 & 0.442474 \\
LNGINI $^{2}$ & 2.25 & 0.444411 \\
FINDEV & 2.10 & 0.475342 \\
EDU & 2.02 & 0.495761 \\
LF & 1.92 & 0.521210 \\
GOVEX & 1.83 & 0.545737 \\
SAV & 1.75 & 0.571767 \\
INFL & 1.70 & 0.587534 \\
Mean VIF & 2.03 & \\
\hline
\end{tabular}

Looking the above table, the mean VIF is less than ten $(2.03<10)$, implying that no multicollinearity problem.

vi. Long Run Model Estimation

The table above (table 4) shows the presence of long run relationship between the dependent and in dependent variables. Accordingly from the estimation, the following results are obtained for the long run model of;

$\ln G D P t=\beta o+\beta 1 \ln G I N I^{2} t+\beta 2 I N F L t+\beta 3 F I N D E V t+\beta 4 S A V t+\beta 5 G O V E X t+\beta 6 E D U t+\beta 7 U R B A t+\beta 8 T R A D E t+\beta 9 L F t+E t$

Table 6. Long run estimation results.

\begin{tabular}{|c|c|c|c|c|c|c|}
\hline \multicolumn{7}{|c|}{ Dependent variable In of real GDP (InGDP) } \\
\hline Variable & Coef. & Std. Err. & $\mathbf{t}$ & $P>t$ & [95\% Conf. & Interval] \\
\hline $\operatorname{lnGINI}^{2}$ & -.8799153 & .3404258 & -2.58 & $0.016^{* *}$ & -1.581035 & -.1787952 \\
\hline INFL & .01957 & .0098895 & 1.98 & $0.059 * * *$ & -.0007978 & .0399378 \\
\hline FINDEV & .0887715 & .0194123 & 4.57 & $0.000 *$ & .0487912 & .1287518 \\
\hline SAV & .0731425 & .0185138 & 3.95 & $0.001 *$ & .0350126 & .1112723 \\
\hline GOVEX & -.0781978 & .0282648 & -2.77 & $0.010 *$ & -.1364103 & -.0199852 \\
\hline EDU & -.0059248 & .0114168 & -0.52 & 0.608 & -.0294382 & .0175886 \\
\hline TRADEO & .0892923 & .0156997 & 5.69 & $0.000 *$ & .0569581 & .1216265 \\
\hline LF & .4320826 & .3276883 & 1.32 & 0.199 & -.2428041 & 1.106969 \\
\hline CONS & 4.336652 & 1.812752 & 2.39 & $0.025 * *$ & .6032194 & 8.070085 \\
\hline \multicolumn{3}{|c|}{ Number of obs $=35$} & \multicolumn{4}{|c|}{ R-squared $=0.9110$} \\
\hline \multicolumn{3}{|c|}{$F(9,25)=28.44$} & \multicolumn{4}{|c|}{ Adj R-squared $=0.8790$} \\
\hline \multicolumn{3}{|c|}{ Prob $>F=0.0000$} & \multicolumn{4}{|c|}{ Root $\mathrm{MSE}=.45927$} \\
\hline
\end{tabular}

$\mathrm{NB}: *$ significant at $1 \% * *$ significant at $5 \% * * *$ significant at $10 \%$

R2-value measures the percentage of variation in the values of the dependent variable $(\ln G D P)$ that can be explained by the variation in the independent variable jointly included in the model. R2-value varies from 0 to 1 . The long run estimation model reveals that the coefficient of determination which is denoted by $R^{2}$ is 0.9110 or 91.1 percent. Its meaning is that 91.1 percent of the variation in real GDP is explained by the given explanatory variable jointly included in the model. The remaining $8.9 \%$ of the variation in the dependent variable $(\ln G D P)$ is presumed to be due to random variability.

The estimated long run model results shows that the entire explanatory variable are statistically significant except primary enrollment rate and labor force which are statistically insignificant. The value of constant term, 4.336 which is also the intercept of 
real GDP and significant at 5\% significance level, interpreted as the value that we would predict for real GDP if all the explanatory variables included in the model are zero. However, this is only a meaningful interpretation if it is reasonable that the entire explanatory variable included in the model can be zero (0), and if the dataset actually included values forpredictor variable that were near 0 . If neither of these conditions is true, then the constant term really has no meaningful interpretation.

As shown in table 6. above, in the long run income inequality has a negative and significant impact on real GDP. The estimated result shows that holding other variable constant, a 1 unit increase in income inequality measured by gini coefficient will cause decrease in real GDP by 0.879 units. This result does not follow Kuznets hypothesis since Ethiopia is a low income country and this would make economic growth and income inequality to rise at the same time. Our case is different. This can be explained by the social problems associated with inequality. These social problems include stealing, corruption, political instability.

vii. The Short Run Model (Dynamics)

ECM (Error correction model) is use to estimate the short run relationship between the variables and to determine the adjustment in the short run shock by differencing the long run model. The short run model can be estimated (ECMT-1) to capture the adjustment towards the long run and the model can be specifying as follows.

$$
\begin{aligned}
D \ln G D P t=\beta o & +\beta 1 D \ln G I N I^{2} t+\beta 2 D I N F L t+\beta 3 D F I N D E V t+\beta 4 D S A V t+\beta 5 D G O V E X t+\beta 6 D E D U t+\beta 7 D U R B A t \\
& +\beta 8 D T R A D E t+\beta 9 D L F t+E t
\end{aligned}
$$

\begin{tabular}{|c|c|c|c|c|c|c|}
\hline \multirow{2}{*}{ Variable } & \multicolumn{6}{|c|}{ Dependent variable real GDP (InGDP) } \\
\hline & Coef. & Std. Err. & $\mathbf{t}$ & $\mathbf{P}>\mathbf{t}$ & \multicolumn{2}{|c|}{ [95\% Conf. Interval] } \\
\hline DlnGINI2 & -.041055 & .0552858 & -0.74 & 0.465 & -.1554225 & .0733124 \\
\hline DINFL & -.0000779 & .0012141 & -0.06 & 0.949 & -.0025894 & .0024335 \\
\hline DFINDEV & -.0405807 & .0072189 & -5.62 & 0.000 & -.0555142 & -.0256472 \\
\hline DSAV & .000673 & .0029747 & 0.23 & 0.823 & -.0054806 & .0068266 \\
\hline DGOV & -.0035845 & .0046754 & -0.77 & 0.451 & -.0132562 & .0060872 \\
\hline DEDU & .0020472 & .0014994 & 1.37 & 0.185 & -.0010545 & .005149 \\
\hline DTRADEO & -.0067562 & .0060224 & -1.12 & 0.274 & -.0192144 & .005702 \\
\hline DLF & .0087046 & .0568806 & 0.15 & 0.880 & -.108962 & .1263711 \\
\hline Ecmt-1 & .0359545 & .0440636 & 0.82 & 0.423 & -.055198 & .1271071 \\
\hline Cons & .148846 & .01267 & 11.75 & 0.000 & .1226362 & .1750558 \\
\hline \multicolumn{3}{|c|}{ Number of obs $=34$} & \multicolumn{4}{|c|}{ R-squared $=0.7201$} \\
\hline \multicolumn{3}{|c|}{$F(10,23)=5.92$} & \multicolumn{4}{|c|}{ Adj R-squared $=0.5984$} \\
\hline \multicolumn{3}{|c|}{ Prob $>F=0.0002$} & \multicolumn{4}{|c|}{ Root $\mathrm{MSE}=.06686$} \\
\hline
\end{tabular}

Table 7. Short run estimation results.

As indicated in the about table 7,2.01\% of the variation in the short run model is explained by the variables included in the model. The lagged error correction (Ecmt-1) indicates that $3.59 \%$ of the shock is adjusted in each year or the shock is eliminated in each year or, it shows $3.59 \%$ of discrepancy between the actual and long run or equilibrium value of real GDP corrected in each year.

\section{Conclusion and Policy Implication}

The general objective of this study is to provide a comprehensive study and critical overviews of the linkage between economic growth and income inequality in Ethiopian economy.

To determine relationship among the variables, simple regression or OLS (ordinary least square) model was applied. Before applying an econometric estimation by using simple regression model, all the variables are tested their stationarity properties using the ducky fuller (DF) tests. As a result, real GDP, inflation rate, primary enrollment rate, and urbanization growth rate are integrated of order zero or stationary (no unit root problem) at level, while income inequality (gini), financial development, gross domestic saving, government expenditure, trade openness and labor force growth are integrated of order one I (1) or stationary at first difference. The residual also stationary at level indicates that the variables are cointegrated. Descriptive analysis also applied to show the trend of both dependent variable (real GDP) and included independent variable.

The empirical result showed that income inequality has a negative and significant impact in the long run but negative and insignificant impact in the short run on country's real GDP. The estimated result shows that holding other variable constant, a $1 \%$ increase in income inequality measured by gini coefficient will cause decrease in real GDP by $87.9 \%$ in the long run and $4.1 \%$ in the short run. This does not support Kuznets hypothesis and the finding found to contradict with Kuznets hypothesis.

The other included determinant of economic growth, as expected financial development has positive and significant impact in the long run but negative and significant impact in the short run. The finding also shows inflation has positive and significant impact in the long run which is inconsistence to prior expectation. The gross domestic savings found to have positive and significant impact on economic growth in the long run which is consistence with the hypothesis. Government expenditure to GDP ratio and urbanization growth contributes negative and significance impact. The proxy variables used for human capital; primary enrollment rate, found to be negative and insignificant impact on economic growth in the long run. 
Based on the analysis made and conclusion arrived the following policy implication are forwarded. The government pursues redistribution of income. The adoption of pro-poor growth policies that aims to boost economic development while paying attention to the interests of the poor and reducing income gap is important to sustain economic growth. The moderate inflation is good because it can result in more productivity, because when inflation rises companies tend to increase their production so as to earn more and at times of prolonged deflation or very low inflation the economy stuck in a recession. Financial market development through appropriate mix of taxes, legal and regulatory policies to remove barriers to financial markets operation are important. Further opening up of the financial sectors in the economy would enhance the efficiency of the sector with positive effect on their growth rates.

\section{References}

[1] Alesina A. and Perotti R. (1996), Income distribution, political instability, and investment. European Economic Review 40 (6): $1203-1228$.

[2] Alesina A. and Rodrick D. (1994), Distributive politics and economic growth, Quarterly Journal of Economics 109, 465490.

[3] Aghion P. (1999), Inequality and economic growth: the perspective of the new growth theories. Journal of Economic Literature 37 (4): 1615-1660.

[4] Banerjee A. and Duflo E. (2003), Inequality and Growth: What Can the Data Say? NBER Working Paper No. 779.

[5] Beza G. (2009), Economic growth and income inequality, AAUBourguignon F. (1981), Pareto Superiority of Unegalitarian Equilibrium inStiglitz' Model of Wealth Distribution with Convex Saving Function, vol. 49, pages1469-75.

[6] Cue M. (1988), Income distribution and economic development: a case study ofthe Kuznets hypothesis applied to Puerto Rico.

[7] Dahan M. and Tsiddon D. (1998), Demographic Transition, Income distribution, and Economic Growth, Washington, D. C.

[8] Deaton A. 2013, What's wrong with inequality? Book Review of Joseph Stieglitz.

[9] Dollar D. and Kraay A. (2002), "Trade growth and poverty", DevelopmentResearch Group, The World Bank.

[10] Easterly, W. (1999), Life during Growth: International Evidence on Quality ofLife and per cápita Income, Journal of Economic Growth, no. 4.

[11] Galor and Zeira J. (1993), Income Distribution and
Macroeconomics, Reviewof Economic Studies, Vol: 60, pages 35-52.

[12] Gideon B. (2012) Economic growth and income inequality: a test of Kuznets inverted U hypothesis, AAU.

[13] Hyse A. (1995), Income distribution and economic growth in developing countries, an empiricalanalysis.

[14] K. Jhe. (1996), Regional Income Inequality and Economic Growth in China. Journal of Comparative Economics; vol 22; pp 141-164.

[15] Kuznets S, (1955), Economic Growth and Income Inequality, AmericanEconomic Review, Vol: 45, No: 1, pages 1-28.

[16] Lee W. and Roemer J. (1998), Income Distribution, Redistributive Politics, and Economic Growth, Journal of Economic Growth, 3 (3), 217-40.

[17] Maddala, G. S. (1992), Introduction to Econometrics, 2nd Edition, Prentice Hall, New Jersey.

[18] Maina A. W. (2006), Income inequality and economic growth in Kenya University of Nairobi.

[19] Melikhova O. (2010), Comment on income Kuznets curve, Charles UniversityPrague.

[20] Montgomery, D. (2001). Introduction to linearregression analysis, 3rd edition, Wiley, New YorkNitisha (2013), Five factors that affect economic growth of a country.

[21] Panizza U. (2002), Income Inequality and Economic Growth: Evidence from American Data. Journal of Economic Growth, 7 (1), 25-41.

[22] Sezeles M. R. (2011), Re-examining the relationship between economic growthand inequality in the new member states. Quality \& Quantity, University of Brasov, Romania. Schulz A., (2010), Economic growth.

[23] SID, 2004, Pulling Apart: Facts and Figures on Equality in Kenya.

[24] Thornton, J. (2001), The Kuznets inverted-U hypothesis: panel data evidence from 96 countries, Applied Economics Letters, vol. 8, no. 1, pp. 15-16.

[25] Todaro M. P, (1994), Economic Development (5th ed.). New York, London: Longman.

[26] Todaro M. P., 2009 Economic Development, 9th edition Long man Publication, New York.

[27] Voitchovsky (2005), Does the Profile of Income Inequality Matter for Economic Growth?Journal of Economic Growth, vol. 10, pages 273-296, 09.

[28] World Bank (2014), World Development Indicators, Washington DC.

[29] World Bank, (2012), World Development Report -Jobs. The World Bank. 